Georgetown University Law Center

Scholarship @ GEORGETOWN LAW

2003

\title{
The New McCarthyism: Repeating History in the War in Terrorism
}

David Cole

Georgetown University Law Center, cole@law.georgetown.edu

This paper can be downloaded free of charge from:

https://scholarship.law.georgetown.edu/facpub/74

38 Harv. C.R.-C.L. L. Rev. 1-30 (2003)

This open-access article is brought to you by the Georgetown Law Library. Posted with permission of the author. Follow this and additional works at: https://scholarship.law.georgetown.edu/facpub

Part of the Civil Rights and Discrimination Commons, and the Criminal Law Commons 


\title{
GEORGETOWN LAW Faculty Publications
}

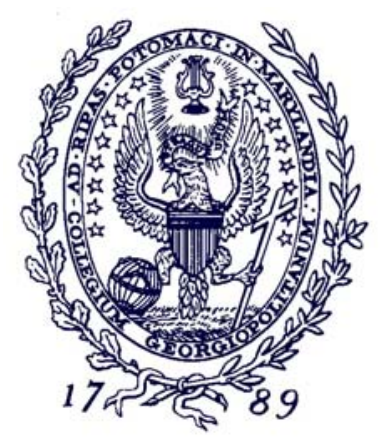 \\ January 2010

\section{The New McCarthyism: Repeating History in the War in Terrorism}

\author{
38 Harv. C.R.-C.L. L. Rev. 1-30 (2003) \\ David Cole \\ Professor of Law \\ Georgetown University Law Center \\ cole@law.georgetown.edu
}

This paper can be downloaded without charge from:

Scholarly Commons: http://scholarship.law.georgetown.edu/facpub/74/

SSRN: $\underline{\text { http: } / / \text { ssrn.com/abstract }=383660}$

Posted with permission of the author 


\section{The New McCarthyism: Repeating History in the War on Terrorism}

\section{David Cole ${ }^{*}$}

The idea of progress is a powerful one. In 1958, in the midst of the Cold War, Yale Law Professor Ralph Brown opened his comprehensive study of the federal government's loyalty and security program by claiming that censorship, "a traditional device for curbing dangerous speech, ... is worthy of mention chiefly because, in the political sphere, the times have passed it by."' Similarly, as we launch a war on terrorism in response to the horrific attacks of September 11, 2001, scholars, government officials, and pundits remind us repeatedly that we have avoided the mistakes of the past: we have not locked up people for merely speaking out against the war, as we did during World War I; we have not interned people based solely on their racial identity, as we did during World War II; and we have not punished people for membership in proscribed groups, as we did during the Cold War. ${ }^{2}$ But we should be careful about too quickly congratulating ourselves. As Brown went on to argue, "The decline of conventional censorship has been more than offset by a new development, censorship of the speaker rather than the speech." 3 The Cold War did most of its damage by targeting people not for their speech, but for their associations. Similarly, while many argue that we have avoided the mistakes of the past in this crisis, it would be more accurate to say that we have adapted the mistakes of the past, substituting new forms of political repression for old ones.

Today's war on terrorism has already demonstrated our government's remarkable ability to evolve its tactics in ways that allow it si-

* Professor, Georgetown University Law Center. I am or was counsel in several of the cases discussed herein, including Reno v. American-Arab Anti-Discrimination Committee, 525 U.S. 471 (1999); Turkmen v. Ashcroft, No. CV-02-307 (E.D.N.Y. 2002); Humanitarian Law Project v. Reno, 205 F.3d 1130 (9th Cir. 2000), cert. denied, 532 U.S. 904 (2001). Kate Didech provided excellent research assistance.

' RalPh S. Brown, Jr., Loyalty and Security: Employment Tests in the United STATES 14 (1958).

${ }^{2}$ See, e.g., Jack Goldsmith \& Cass R. Sunstein, Military Tribunals and Legal Culture: What a Difference Sixty Years Makes (Univ. of Chi. Law School, Public Law \& Legal Theory Working Paper No. 27, 2002), available at http://www.law.uchicago. edu/academics/publiclaw/resources/27.jg-cs.tribunals.pdf; Pam Belluck, Hue and Murmur Over Curbed Rights, N.Y. TIMEs, Nov. 17, 2001, at B8; Marty Meehan, Editorial, More Tools Needed to Fight Terrorism, Boston Herald, Oct. 3, 2001, at 29; Jeffrey Rosen, Liberty Wins-So Far; Bush Runs Into Checks and Balances in Demanding New Powers, Wash. Post, Sept. 15, 2002, at B2; Jeffrey Rosen, What Price Security?; Testing the Resilience of American Values, N.Y. TIMES, Nov. 18, 2001, § 4, at 1.

${ }^{3}$ BRown, supra note 1 , at 14-15. 
multaneously to repeat history and to insist that it is not repeating history. We have not, it is true, interned people solely for their race, but we have detained approximately two thousand people, mostly through administrative rather than criminal procedures, and largely because of their ethnic identity. ${ }^{4}$ In addition, we have subjected Arab and Muslim noncitizens to discriminatory deportation, registration, fingerprinting, visa processing, and interviews based on little more than their country of origin. ${ }^{5}$ We have not, it is true, made it a crime to be a member of a terrorist group, but we have made guilt by association the linchpin of the war's strategy, penalizing people under criminal and immigration laws for providing "material support" to politically selected "terrorist" groups, without regard to whether an individual's support was intended to further or in fact furthered any terrorist activity.

In short, just as we did in the McCarthy era, we have offset the decline of traditional forms of repression with the development of new forms of repression. A historical comparison reveals not so much a repudiation as an evolution of political repression.

I do not mean to suggest that the Cold War and today's war on terrorism are in all respects identical. History never repeats itself in that literal a sense. For one thing, fear of ideas played a much larger role in the Cold War. Our concerns today stem more from the fear of catastrophic violence made possible by weapons of mass destruction and an enemy that appears immune to deterrence. We who witnessed the World Trade Center towers burn and fall will never forget the horrors of that day. But it is too easy in hindsight to minimize the threat that the nation felt during the Cold War. Then, we were threatened not by a terrorist gang of a few thousand men but by the second largest superpower in the world. Now we speculate about whether the enemy has access to weapons of mass destruction. Then, we knew that there were thousands of nuclear bombs trained on our cities. Many of us have nightmares of terrorist attacks today, but at least as many had nightmares then of a nuclear Armageddon. ${ }^{6}$ In short, both periods unquestionably were times of mass fear.

As John Lord O'Brian argued in the midst of the Cold War, great fear inevitably produces calls for "preventive" law enforcement; we seek not merely to punish perpetrators after the fact but to prevent the next

${ }^{4}$ See infra text accompanying notes 92-108.

5See Am. Immigration Lawyers Ass'n, Immigration, Security, and Civil LiberTIES (AlLA Issue Paper No. 21 ip2001, May 30, 2002), available at http://www.aila.org/ contentViewer.aspx ?bc $=9,722,808$; Neil A. Lewis \& Christopher Marquis, Longer Visa Waits for Arabs; Stir over U.S. Eavesdropping, N.Y. TIMES, Nov. 10, 2001, at A1; Susan Sachs, For Many American Muslims, Complaints of Quiet but Persistent Bias, N.Y. TImes, Apr. 25, 2002, at A16; Susan Sachs, Government Ready to Fingerprint and Keep Track of Some Foreign Visitors, N.Y. Times, Sept. 9, 2002, at A16.

${ }^{6}$ See Jonathan Schell, The Fate of the Earth (1982) (on the threat of nuclear annihilation). 
disaster from occurring. ${ }^{7}$ Attorney General John Ashcroft has proudly proclaimed the "preventive" features of his campaign against terrorism. ${ }^{8}$ But preventive justice and criminal law are not an easy mix; the fact that the criminal sanction requires the commission of a crime and insists on a strong presumption of innocence until guilt is proven beyond a reasonable doubt makes the criminal law an unwieldy mechanism for prevention. Prevention is not of course impossible to achieve through the criminal process. In theory, deterrence operates to prevent crimes, although deterrence is not very realistic when perpetrators are willing to sacrifice their own lives. And the crimes of conspiracy and attempts mean that we do not have to wait for the bomb to explode before arresting individuals and invoking criminal sanctions. Sheikh Omar Abdel Rahman is currently serving multiple life sentences for his role in planning to bomb the tunnels and bridges around Manhattan-the bombs never went off, yet we were able to prosecute the planners on conspiracy charges and incarcerate them for the rest of their lives. ${ }^{9}$

Still, the criminal process, with its rights to counsel, confrontation of adverse witnesses, public trial, and the presumption of innocence, undoubtedly makes preventive law enforcement more difficult. Accordingly, in times of fear, government often looks for ways to engage in prevention without being subject to the rigors of the criminal process. This Essay will argue that the government has invoked two methods in particular in virtually every time of fear. The first, discussed in Part I, involves a substantive expansion of the terms of responsibility. Authorities target individuals not for what they do or have done but based on predictions about what they might do. These predictions often rely on the individuals' skin color, nationality, or political and religious associations. The second method, the subject of Part II, is procedural-the government invokes administrative processes to control, precisely so that it can avoid the guarantees associated with the criminal process. In hindsight, these responses are virtually always considered mistakes. They invite excesses and abuses, as many innocents suffer without any evident gain in security. And most significantly, they compromise our most basic principles-commitments to equal treatment, political freedoms, individualized justice, and the rule of law.

In the current war on terrorism, just as in prior times of fear, our government has adopted both substantive and procedural shortcuts toward the end of preventive justice. While it has altered slightly the tactics of prevention to avoid literally repeating history, in its basic approach the government today is replaying the mistakes of the past. All we have

7 John Lord O'Brian, National Security and Individual Freedom 24-25 (1955).

${ }^{8}$ See infra note 98.

${ }^{9}$ United States v. Rahman, 189 F.3d 88 (2d Cir. 1999), cert. denied, 528 U.S. 1094 (2000). 
learned from history is how to mask the repetition, not how to avoid the mistakes.

\section{A Rose by Any Other Name-Subversive Speech, Guilt by Association, and Material Support}

The most direct way to authorize preventive law enforcement is to redefine liability broadly so that authorities can sweep up large numbers of people without having to prove that individuals have engaged in specific harmful conduct. In our history, this has been accomplished in two principal ways-by targeting people for what they say before they act and for their associations. In today's war on terrorism, liability has been redefined by penalizing people for "material support" to proscribed groups.

\section{A. Censoring Subversive Speech}

In the beginning, we targeted the word. In World War I, Congress made it a crime to utter "any disloyal, profane, scurrilous, or abusive language ... as regards the form of government of the United States, or the Constitution, or the flag." 10 Over two thousand persons were prosecuted, essentially for speaking out against the war. ${ }^{11}$ The Supreme Court affirmed the Sedition Act's constitutionality in a handful of cases at war's end. ${ }^{12}$ Few groups or individuals criticized this state of affairs. When Harvard Law Professor Zechariah Chafee did so, Harvard brought him up on charges of being unfit to be a professor. He was acquitted, but only by the narrowest of margins, six to five. It was later revealed that the Justice Department had helped prepare the charges against Professor Chafee. ${ }^{13}$

Today, by contrast, no law criminalizes speaking out against the war; plenty of people have done so, and, with rare exceptions, few have been punished for it. Sami Al-Arian, a tenured computer science professor at the University of South Florida (USF), is one exception. Shortly after September 11, Professor Al-Arian appeared on Fox Television's The $O$ 'Reilly Factor, and the program took the occasion to air clips from speeches Professor Al-Arian had made at off-campus pro-Palestinian rallies during the late 1980s in which he chanted, "Death to Israel." When the show aired, USF and Professor Al-Arian received a number of threat-

${ }^{10}$ Sedition Act of 1918, ch. 75, 40 Stat. 553, repealed by Act of Mar. 3, 1921, ch. 136, 41 Stat. 1359.

"See Zechariah Chafee, Free Speech in the United States 51 (1948).

${ }^{12}$ Gilbert v. Minnesota, 254 U.S. 325 (1920); Abrams v. United States, 250 U.S. 616 (1919); Debs v. United States, 249 U.S. 211 (1919); Frohwerk v. United States, 249 U.S. 204 (1919); Schenck v. United States, 249 U.S. 47 (1919).

${ }^{13}$ See Peter H. Irons, "Fighting Fair": Zechariah Chafee, Jr, the Department of Justice, and the "Trial at the Harvard Club," 94 HARv. L. Rev. 1205 (1981). 
ening calls. Some threatened violence against Al-Arian; others, no doubt, asked why the university was maintaining on its payroll someone with such extreme views. The governor himself weighed in against Al-Arian. The university suspended the professor and threatened to terminate him, maintaining that his off-campus statements, together with the difficulty in protecting him and his students from threats sparked by the reporting of the statements, warranted dismissal. ${ }^{14}$

But the most remarkable thing about the Al-Arian case is how atypical it is. In stark contrast to their performance during the Cold War, universities generally have been tolerant of dissenting voices. The American Association of University Professors has threatened to censure USF if it terminates Professor Al-Arian. ${ }^{15}$ Right-wing organizations have been roundly criticized when they have suggested the need to monitor campuses for anti-patriotic teaching and activity, as Lynne Cheney's American Association of Trustees and Alumni did in its November 2001 report, Defending Civilization: How Our Universities are Failing America and What Can be Done About It. ${ }^{16}$ The report listed 117 instances of unpatriotic speech by identified university professors and called American faculty "the weak link in America's response" to September 11. The Boston Globe dismissed the report as "McCarthyesque," 17 the New York Times labeled it "repugnant,"18 and a Philadelphia Inquirer column called it "the Taliban-ization of America."19 Similarly, when Attorney General John Ashcroft told Congress that those who faulted him on civil liberties grounds were aiding the enemy, his comments, too, were quickly and

${ }^{14}$ Stephen Buckley, The Al-Arian Argument, St. Petersburg Times, Mar. 3, 2002, at IA, 2002 WL 15926430; Sharon Walsh, Blaming the Victim? A University Vows to Fire a Tenured Professor Facing Death Threats in the Wake of September 11, CHRON. Higher EDUC., Feb. 8, 2002, at A10.

${ }^{15}$ Press Release, American Association of University Professors, An Interim Statement on Al-Arian Released (June 8, 2002), available at http://www.aaup.org/newsroom/press/ 2002/02-6usf.htm (stating that "[t]he investigating committee believes that Professor AlArian's statements fell well within the ambit of academic freedom" and that "[0]ther currently pending charges against Professor Al-Arian have been characterized by the investigating committee as too insubstantial to warrant serious consideration as adequate cause for dismissal"); see also Rob Brannon, AAUP Restates Stern Warning to USF, U.S. FLA. ORACLE, June 13, 2002, available at http://www.usforacle.com/vnews/display.v/ART/2002/06/ $13 / 3 \mathrm{~d} 088 \mathrm{a} 6 \mathrm{e} 2 \mathrm{c} 734$ ? in_archive $=1$.

${ }^{15}$ The revised and expanded report, released in February 2002, is available at http://www.goacta.org/Reports/defciv.pdf. The originally issued version of the report included the names and statements of individual professors, but after considerable negative media coverage, the organization issued an edited version without naming individuals. The original report, issued in November 2001, is available at http://www.eecs.harvard.edu/ aaron/defciv.pdf. See generally Emily Eakin, On the Lookout for Patriotic Incorrectness, N.Y. Times, Nov. 24, 2001, at A15; Hugh Gusterson, The Weakest Link? Academic Dissent in the "War on Terrorism," paper delivered at Loyalty and Dissent in Dangerous Times Conference (Apr. 5-6, 2002) (on file with author).

${ }^{17}$ Editorial, Up With Dissent, Boston Globe, Nov. 20, 2001, at A20.

${ }^{18}$ Protecting Speech on Campus, N.Y. Times, Jan. 27, 2002, § 4, at 12.

${ }^{19}$ Alfred Lubrano, Flaunting Patriotism of a Nasty Stripe, PhILA. Inquirer, Nov. 27, 2001 , at $\mathrm{Cl}$. 
broadly condemned. ${ }^{20}$ Newspapers, scholars, activists, and human rights and civil rights organizations across the country have openly criticized the Administration's response to the September 11 attacks and do not seem to have suffered for doing so. This should not come as much of a surprise. Already in the 1950 s, as Professor Brown reported, traditional political censorship seemed to be on the way out. But as censorship of ideas fell into disrepute, the government simply shifted tactics, substituting guilt by association for punishment of speech.

\section{B. Guilt by Association}

In the Cold War, most "radicals" were punished not for their speech but for their membership, affiliation, or sympathetic association with the Communist Party. This did not mean that people were free to speak, of course, because speech was often used as evidence of one's connection to or sympathy for the Communist Party. ${ }^{21}$ But the government could claim that it was avoiding the mistakes of World War I censorship, even as it was effectively suppressing political dissent by targeting communist associations and sweeping a wide swath of progressive political groups under the "communist" label. In November 1950, for example, the Attorney General had placed nearly two hundred groups on a list of communist and other subversive organizations, affiliation with which could lead to

${ }^{20}$ In testimony before the Senate Judiciary Committee, Attorney General Ashcroft stated:

To those who pit Americans against immigrants and citizens against non-citizens; to those who scare peace-loving people with phantoms of lost liberty; my message is this: Your tactics only aid terrorists-for they erode our national unity and diminish our resolve. They give ammunition to America's enemies, and pause to America's friends.

DOJ Oversight: Preserving our Freedoms while Defending Against Terrorism: Hearing Before the Senate Comm. on the Judiciary, 107th Cong. (2001), available at http://www. senate.gov/\%7Ejudiciary/testimony.cfm?id=121\&wit_id=42. Criticism of Ashcroft's statement was quick to follow. See, e.g., Dan Eggen, Ashcroft Defends Anti-Terrorism Steps; Civil Liberties Groups' Attacks "Only Aid Terrorists," Senate Panel Told, WaSH. Post, Dec. 7, 2001, at Al; Neil A. Lewis, Ashcroft Defends Antiterror Plan; Says Criticism May Aid U.S. Foes, N.Y. TImes, Dec. 7, 2001, at A1; Frank Rich, Confessions of a Traitor, N.Y. Times, Dec. 8, 2001, at A23; Editorial, John Ashcroft Misses the Point, N.Y. Times, Dec. 7, 2001, at A30; Editorial, Shades of Gray, St. Louis Post-DisPatch, Dec. 9, 2001, at B2; Editorial, On Civil Liberties: Under Cloak of "Security," S.F. Chron., Dec. 9, 2001, at D4, 2001 WL 3422016.

${ }^{21}$ By its terms, the Smith Act punished speech-advocacy of the overthrow of the United States government by force or violence-and many Communists, including the national leadership of the party, were prosecuted for conspiracy to so advocate and for conspiracy to organize a group to so advocate. See generally United States v. Dennis, 341 U.S. 494 (1951); Michael Belknap, Cold War Political Justice: The Smith ACt, the Communist Party, and American Civil Liberties (1977); Arthur J. Sabin, In Calmer Times: The Supreme Court and Red Monday (1999); William M. Wiecek, The Legal Foundations of Domestic Anticommunism: The Background of Dennis v. United States, 2001 Sup. CT. Rev. 375. 
such consequences as losing a job or being called before the House UnAmerican Activities Committee (HUAC). ${ }^{22}$

In terms of their effects, guilt by association and censorship of subversive speech are remarkably similar. From the public's vantage point, they demarcate certain political positions as off-limits and dangerous. And because what is proscribed is nearly always defined in open-ended terms or by inscrutable processes, both censorship and guilt by association have an even wider chilling effect, making members of the public leery of engaging in any political activity that might potentially be condemned. From the government's perspective, both tactics facilitate preventive law enforcement. In World War I, anti-war protesters could be silenced and suppressed before their words were translated into any antiwar action. Similarly, if we can target people for their associations, we can disrupt the organization of movements that might someday lead to criminal activity, without having to prove that particular individuals intended to further illegal activity of any kind. The Communist Party never actually took any concrete steps to overthrow the United States government by force or violence, but because its rhetoric was interpreted as so advocating, the government was able to control and ultimately decimate the Party through guilt by association.

Today, of course, the punishment of dissent during World War I and of political association during the Cold War is seen as a grave error. The Supreme Court, to its credit, although largely after the fact, has developed constitutional doctrines that make these particular mistakes difficult to repeat. On the question of subversive speech, the Court first drew an important line between abstract advocacy and advocacy of illegal conduct in 1957, thereby ending prosecution of Communists for their group's advocacy ${ }^{23}$ In 1969, the Court further developed the test in Brandenburg v. Ohio ${ }^{24}$ requiring the government to show that an individual's speech was intended and likely to produce imminent illegal conduct, a threshold that for all practical purposes requires proof of an actual conspiracy to engage in criminal conduct.

In a series of cases beginning as the Cold War was winding down, the Supreme Court also prohibited guilt by association, ultimately declaring it to be "alien to the traditions of a free society and to the First Amendment itself." 25 The prohibition had its genesis in Scales $v$. United

${ }^{22}$ Eleanor Bontecou, The Federal Loyalty-Security Program 171 (1953); see $i d$. at 157-204 (discussing the makeup, evolution, and uses of the Attorney General's lists).

${ }^{23}$ See Yates v. United States, 354 U.S. 298, 318 (1957). The Yates decision effectively ended prosecutions under the advocacy sections of the Smith Act. See SABIN, supra note 21 , at $10-11$.

${ }^{24} 395$ U.S. 444 (1969).

${ }^{25}$ NAACP v. Claiborne Hardware Co., 458 U.S. 886, 932 (1982) (citations omitted). 
States, ${ }^{26}$ which effectively ended prosecutions for Communist Party membership under the Smith Act. As the Court stated:

In our jurisprudence guilt is personal, and when the imposition of punishment on a status or on conduct can only be justified by reference to the relationship of that status or conduct to other concededly criminal activity ... that relationship must be sufficiently substantial to satisfy the concept of personal guilt in order to withstand attack under the Due Process Clause of the Fifth Amendment. ${ }^{27}$

The Court explained that groups often engage in both lawful and unlawful activities and that both the Due Process Clause and the First Amendment forbid punishing individuals who support only a group's lawful ends. ${ }^{28}$ Driven by these constitutional concerns, the Court interpreted the Smith Act to require proof that an individual specifically intended to further the unlawful ends of the Communist Party. The Court then extended that principle in subsequent cases to bar imposition even of civil penalties-including tort liability ${ }^{29}$ and denial of employment, ${ }^{30}$ security clearance, ${ }^{31}$ passports, ${ }^{32}$ and even access to student meeting rooms ${ }^{33}$-absent proof of specific intent to further a group's unlawful activity.

These constitutional bulwarks, however, have not ended the desire for preventive law enforcement in times of crisis. Government officials pressed by the public to prevent the next terrorist attack, but barred by history and the Constitution from targeting people for their speech or associations, have sought to develop other ways of implementing preventive law enforcement. The principal substantive innovation in the war on terrorism has been the targeting of material support to terrorist groups.

\section{Material Support}

The targeting of material support to terrorist organizations is the linchpin of the government's current war on terrorism. Federal law makes it a deportable offense and a crime to provide "material support" to terrorist organizations, ${ }^{34}$ and the United States vigorously has pushed other

${ }^{26} 367$ U.S. 203 (1961).

${ }^{27} \mathrm{Id}$. at $224-25$.

${ }^{28}$ Id. at 224-25, 229-30.

${ }^{29}$ Claiborne Hardware Co., 458 U.S. at 932.

${ }^{30}$ See Elfbrandt v. Russell, 384 U.S. 11, 19 (1966).

${ }^{31}$ See United States v. Robel, 389 U.S. 258, 265-66 (1967).

${ }^{32}$ See Aptheker v. Sec'y of State, 378 U.S. 500, 510-12 (1964).

${ }^{33}$ See Healy v. James, 408 U.S. 169, 186-87 (1972).

${ }^{34} 8$ U.S.C. $\S 1182(\mathrm{a})(3)(\mathrm{B})(\mathrm{iv})(\mathrm{VI})$ (West Supp. 2002); 18 U.S.C.A. $\S 2339 \mathrm{~B}$ (West $2000 \&$ Supp. 2002) 
nations to enact similar laws. ${ }^{35}$ Virtually every criminal "terrorism" case that the government has filed since September 11 has included a charge that the defendant provided material support to a terrorist organization. ${ }^{36}$ And the government effectively has closed down three of the largest Muslim charities in the United States based on broad allegations of potential terrorist financing. ${ }^{37}$

The reason the material support laws have proven so popular with federal prosecutors is that, like the speech and membership provisions of World War I and the Cold War, these laws do not require proof that an individual intended to further any terrorist activity. Under the criminal material support statute, for example, it is a crime to provide material support-defined expansively to include any "physical asset," as well as "personnel," "training," or "expert advice or assistance"38_to a designated terrorist organization, without regard to the purpose or effect of the

${ }^{35}$ See, e.g., International Convention for the Suppression of the Financing of Terrorism, G.A. Res. 54/109, U.N. GAOR, 4th Sess., U.N. Doc. A/RES/54/109 (1999); Kurt Eichenwald, Global Plan To Track Terror Funds, N.Y. TimEs, Dec. 19, 2001, at B5; Jeff Gerth \& Judith Miller, Report Says Saudis Fail to Crack Down on Charities That Finance Terrorists, N.Y. TimES, Oct. 17, 2002, at A20; Serge Schmemann, U.N. Gets a Litany of Antiterror Plans, N.Y. Times, Jan. 12, 2002, at A7.

${ }^{36}$ John Walker Lindh, the so-called "American Taliban," was charged with providing material support to two terrorist organizations by attending their training camps. See Indictment at 10-14, United States v. Lindh, No. CR. 02-37a (E.D. Va. Oct. 4, 2002), available at http://news.findlaw.com/hdocs/docs/terrorism/uswlindh020502 cmp.html. Lynne Stewart, the attorney for Sheikh Omar Abdel Rahman, has been charged with providing material support to an Egyptian terrorist organization by facilitating communications between the Sheikh and the group. See Indictment at 10-20, United States v. Sattar, No. CR. 02-395 (S.D.N.Y. Apr. 4, 2002), available at http://news.findlaw.com/hdocs/docs/terrorism/ ussattar040902ind.pdf. Five young men from Lackawanna, New York, have been charged under the material support statute for attending an Al Qaeda training camp. See Indictment, United States v. Goba, No. 02-M-107 (W.D.N.Y. Oct. 21, 2002), available at http://news. findlaw.com/hdocs/docs/terrorism/usgoba102102ind.html. James Ujaama, a Seattle activist, has been charged with providing material support by planning to set up a training camp in the United States for Al Qaeda. See Indictment, United States v. Ujaama (W.D. Wash. Aug. 28, 2002), available at http://news. findlaw.com/hdocs/docs/terrorism/ usujaama82802ind.pdf. A group in Portland has been charged under the material support statute for seeking to fight in Afghanistan on behalf of Al Qaeda. See Indictment at 12-13, United States v. Battle, CR-02-399 (D. Or. Oct. 3, 2002), available at http://news. findlaw. $\mathrm{com} / \mathrm{hdocs} /$ docs/terrorism/usbattle100302ind.pdf. Finally, a group of men in Detroit has been charged under the same statute for allegedly operating as an underground support unit for terrorist attacks and a "sleeper" operational combat cell. See Indictment at 6-17, United States v. Koubriti, No. 01-80778 (E.D. Mich. Aug. 28, 2002), available at http:// news.findlaw.com/hdocs/docs/terrorism/uskoubriti82802ind.pdf.

${ }^{37}$ See John Mintz, Muslim Charity Leader Indicted, WASH. Post, Oct. 10, 2002, at A14 (Benevolence International Foundation); John Mintz, U.S. Labels Muslim Charity as Terrorist Group, WASH. Post, Oct. 19, 2002, at A2 (Global Relief Foundation); John Mintz \& Neely Tucker, Judge Backs U.S. on Assets Seizure, WASH. Post, Aug. 10, 2002, at A12 (Holy Land Foundation for Relief and Development).

3818 U.S.C.A. \& 2339A(b) (West Supp. 2002) (defining material support or resources as "currency or monetary instruments or financial securities, financial services, lodging, training, expert advice or assistance, safehouses, false documentation or identification, communications equipment, facilities, weapons, lethal substances, explosives, personnel, transportation, and other physical assets, except medicine or religious materials"). 
actual support provided. ${ }^{39}$ Under this law it would be a crime for a Quaker to send a book on Ghandi's theory of nonviolence-a "physical asset"- to the leader of a terrorist organization in hopes of persuading him to forgo violence. Indeed, the Quaker would have no defense even if he could show that his efforts had succeeded in convincing the group to end its violent ways. Similarly, if this law had been on the books in the 1980 s, the thousands of Americans who donated money to the African National Congress (ANC) for its lawful political struggle against apartheid would face lengthy prison terms, because during those years the ANC was designated as a terrorist organization by our State Department.

The material support law is a classic instance of guilt by association. It imposes liability regardless of an individual's own intentions or purposes, based solely on the individual's connection to others who have committed illegal acts. Moreover, it imposes liability highly selectively. The law does not prohibit neutrally all material support to foreign organizations or even all material support to foreign organizations that use violence. Rather, it selectively prohibits material support only to those groups that the Secretary of State in his discretion chooses to designate. The statute gives the Secretary of State a virtual blank check in designating groups; he can designate any foreign organization that has ever used or threatened to use a weapon against person or property and whose activities are contrary to our foreign policy, national defense, or economic interests. ${ }^{40}$ Undoubtedly thousands of groups around the world meet the first criterion, and therefore, the second criterion does virtually all the work in selecting the handful that actually gets designated. ${ }^{41}$ Yet, because the Secretary of State defines our foreign policy, his determination that a group's activities undermine our foreign policy is unreviewable. $^{42}$

The government contends that the material support statute does not violate the Supreme Court's guilt by association principle because it does not criminalize membership per se, but only material support. The government argues that people remain free to join or associate with designated "foreign terrorist organizations" and are barred merely from providing them any material support. On this view, adopted thus far by the

${ }^{39} 18$ U.S.C.A. $\S 2339 B$ (West 2000 \& Supp. 2002).

${ }^{40}$ See 8 U.S.C.A $\$ 1189$ (a)(1), (c)(2) (West 1999 \& Supp. 2002) (setting forth criteria for designation of terrorist organizations).

${ }^{41}$ The Secretary of State's first designation under the law listed thirty organizations. Designation of Foreign Terrorist Organizations, 62 Fed. Reg. 52,650 (Oct. 8, 1997). The list has expanded since September 11, but still includes only thirty-five organizations. Fact Sheet, Office of Counterterrorism, U.S. Department of State, Foreign Terrorist Organizations (Oct. 23, 2002), available at http://www.state.gov/s/ct/rls/fs/2002/12389.htm. Prominent terrorist groups like the Irish Republican Army are notably not on the list.

${ }^{42}$ Peoples' Mojahedin Org. of Iran v. United States Dep't of State, 182 F.3d 17, 23 (D.C. Cir. 1999) (holding that the Secretary of State's determination that an organization's activities undermine national foreign policy for purposes of designating terrorist groups is a judicially unreviewable political question), cert. denied, 529 U.S. 1104 (2000). 
Court of Appeals for the Ninth Circuit, the prohibition on guilt by association applies only to laws that hinge penalties on membership alone..$^{43}$

But the distinction between association and material support is illusory. Groups cannot exist without the material support of their members and associates. If the right of association meant only that one had the right to join organizations but not to support them, the right would be empty. Indeed, if this view were correct, all the laws that the Supreme Court faulted for imposing guilt by association could have been cured simply by hinging penalties not on the fact of membership, but on dues payments, volunteering, or monetary contributions-the very evidence generally advanced to prove membership. Surely the Supreme Court did not insist so strongly on the prohibition on guilt by association for it to be vulnerable to such a formalistic end run.

It is precisely for this reason that the Court has consistently recognized that soliciting donations and making contributions are acts of association protected by the First Amendment. As the Supreme Court has said, "[T] ideas' . . . is diluted if it does not include the right to pool money through contributions, for funds are often essential if 'advocacy' is to be truly or optimally 'effective."' 44 The Court has permitted the capping of political campaign contributions, but only after concluding that the limits imposed neutrally across the board satisfied heightened scrutiny..$^{45}$ The material support law, by contrast, is analogous to a law permitting the Federal Election Commission to selectively criminalize all donations to any political party that it determines engages in some illegal activity and undermines American policy.

Some argue that the guilt by association principle ought not apply to the provision of material support to terrorist groups because money is fungible, so any support of a terrorist group will at a minimum have the indirect effect of furthering terrorism. ${ }^{46}$ In enacting the criminal material support statute, for example, Congress found that "foreign organizations

${ }^{43}$ See Humanitarian Law Project v. Reno, 205 F.3d 1130, 1133 (9th Cir. 2000), cert. denied, 532 U.S. 904 (2001).

${ }^{44}$ Buckley v. Valeo, 424 U.S. 1, 65-66 (1976) (quoting NAACP v. Alabama ex rel. Patterson, 357 U.S. 449, 460 (1958)). Monetary contributions to political organizations are a protected form of association and expression. See id. at 16-17, 24-25; Citizens Against Rent Control/Coalition for Fair Hous. v. City of Berkeley, 454 U.S. 290, 295-96 (1981) (holding that monetary contributions to a group are a form of "collective expression" protected by the right of association); In re Asbestos Litig., 46 F.3d 1284, 1290 (3d Cir. 1994) (holding that contributions to political organizations are constitutionally protected absent specific intent to further a group's illegal ends); Serv. Employees Int'l Union v. Fair Political Practices Comm'n, 955 F.2d 1312, 1316 (9th Cir. 1992) (stating that "contributing money is an act of political association that is protected by the First Amendment").

${ }^{45}$ See Buckley, 424 U.S. at 28.

${ }^{46}$ See Humanitarian Law Project, 205 F.3d at 1134; Gerald Neuman, Terrorism, Selective Deportation and the First Amendment after Reno v. AADC, 14 GEo. IMMIGR. L.J. $313,329-30(2000)$. 
that engage in terrorist activity are so tainted by their criminal conduct that any contribution to such an organization facilitates that conduct." ${ }^{37}$ But this is less a factual "finding" than a normative claim. The legislative history of the material support law contains not one word of testimony about even a single terrorist organization's finances, much less all "foreign organizations that engage in terrorist activity." A congressional "finding" that "domestic political parties that engage in illegal conduct are so tainted by their criminal conduct that any contribution facilitates that conduct" surely would not authorize imposing guilt by association on support of domestic groups. It should have no greater effect with respect to "foreign terrorist organizations."

To be sure, money is fungible. But that is true of all money and all groups, domestic or foreign, political parties or militant terrorists. And for that reason, the argument proves far too much. If accepted, it would mean that legislatures could penalize material support of any organization that has ever engaged in any illegal activity, without regard to the purpose and use of the particular material support. The state could make it a crime to provide newspapers or social services to gang members, to pay dues to the Communist Party, or to make a donation to the Republican Party, on the grounds that each of these organizations has engaged and may in the future engage in illegal activity and that giving them material support would free up resources that could then be used to further the group's illegal ends. The United States unsuccessfully made just such a broad "freeing up" argument to the Supreme Court in Scales v. United States as a reason for rejecting the specific intent test. ${ }^{48}$ The argument should hold no greater sway today.

Finally, the freeing up argument surely overstates the extent to which donations to a group's lawful activities are in practice translated into illegal activities. No one would seriously suggest, for example, that the millions of dollars donated to the ANC in the 1980s to support its lawful anti-apartheid work were simply transformed into bombs and weapons for its military wing. Most "terrorist organizations" do not exist for the purpose of engaging in terrorism. They generally have a political purpose or goal-for example, ending apartheid in South Africa or obtaining selfdetermination for Palestinians in the occupied territories-and use a variety of means to attain that end. Some of those means may be terrorist and some may be perfectly lawful. But it simply does not follow that all organizations that use or threaten to use violence will turn any donation that supports their lawful activities into money for terrorism. According

\footnotetext{
${ }^{47}$ Antiterrorism and Effective Death Penalty Act of 1996, Pub. L. No. 104-132, $\$ 301$ (a)(7), 110 Stat. $1214,1247$.

${ }^{48}$ Brief for the United States on Reargument at 8, Scales v. United States, 367 U.S. 203 (1961) (No. 1) (arguing that a showing of "specific intent" is unnecessary "on the principle that knowingly joining an organization with illegal objectives contributes to the attainment of those objectives because of the support given by membership itself").
} 
to a senior Israeli military officer, even Hamas, the organization reportedly responsible for an untold number of unspeakable suicide bombings in Israel, spends ninety-five percent of its resources on a broad range of social services. ${ }^{49}$ Indeed, in 1994, both the State Department and the Immigration and Naturalization Service opposed a law barring entry to members of Hamas, arguing that because Hamas engages in a wide range of lawful activities, one cannot presume that a Hamas member has anything to do with terrorism. ${ }^{50}$ Yet the material support law presumes that even a donation of crayons to a day-care center affiliated with Hamas will "facilitate" terrorism.

Cutting off material support for terrorist activity is undoubtedly a worthy and appropriate goal. But that can be done without indulging in guilt by association. When the Antiterrorism and Effective Death Penalty Act of 1996 added the current material support provision, it was already a crime to provide material support to anyone-individual, group, or government-for the purpose of engaging in terrorist activity. ${ }^{51}$ Similarly, as the war on organized crime demonstrated, racketeering and money laundering laws authorize the government to criminalize "fronts" used to support criminal activity and the laundering of money for illegal purposes. These laws permit the government to punish those who raise funds for terrorist activity without penalizing constitutionally protected associational activity. ${ }^{52}$ The government recently indicted the director of a Chicago-based Muslim charity on charges of money laundering, misleading donors about the use of their funds, and providing material support to terrorist activity. ${ }^{53}$ The government's rhetorical case against the director continues to rely on guilt by association-it charges, for example, that he was associated with Al Qaeda leaders, failing to acknowledge that his alleged associations occurred in the 1980s, when the United States itself was supporting future Al Qaeda leaders in their fight against the Soviet-backed government of Afghanistan. But rhetoric aside, the government's legal charges do not rest on guilt by association.

${ }^{49}$ See Serge Schmemann, Cradle to Grave: Terror Isn't Alone as a Threat to Mideast Peace, N.Y. Times, Mar. 3, 1996, at D1.

${ }^{50}$ See Criminal Aliens: Hearing Before the Subcomm. on Int'l Law, Immigration, and Refugees of the House Comm. on the Judiciary, 103d Cong. 164 (1994) (prepared statement of Mary A. Ryan, Assistant Secretary for Consular Affairs, U.S. Department of State); see also id. at 180 (written testimony of Chris Sale, Deputy Commissioner of the Immigration \& Naturalization Service).

${ }^{51}$ See 18 U.S.C.A. $§ 2339$ A (West Supp. 2002) (criminalizing material support of terrorist activity).

${ }^{52} \mathrm{See}$ Racketeer Influenced and Corrupt Organizations (RICO) Act, 18 U.S.C.A. $\S \S 1961-1968$ (West 2000 \& Supp. 2002); Money Laundering Control Act of 1986, 18 U.S.C.A. $\$ \S 1956-1957$ (West 2000 \& Supp. 2002) (forfeiture of property is authorized by 18 U.S.C.A. $\$ \S 981-982$ (West $2000 \&$ Supp. 2002)).

${ }^{33}$ See Indictment, United States v. Arnaout, No. 02-CR-892 (N.D. Ill. Nov. 1, 2002), available at http://news. findlaw.com/hdocs/docs/terrorism/usarnaout 10902 ind.pdf. 
An organization like Al Qaeda may present a special case, for it does not appear to have legal purposes at all. Unlike, say, the Irish Republican Army, the Palestinian Liberation Organization, or the ANC, groups with political agendas that use violent means among many others, Al Qaeda appears to do little more than plot, train for, and conduct terrorism. But if that is the case, we do not need guilt by association. It ought to be relatively simple to establish that when an individual affirmatively supports $\mathrm{Al}$ Qaeda, he intends to support its terrorist ends, because Al Qaeda has few if any other ends.

The extent to which the material support statute imposes guilt by association is perhaps best illustrated by two current cases. In the first, the Humanitarian Law Project (HLP) has sued the Attorney General to challenge the constitutionality of the material support statute as it applies to the HLP's conduct. ${ }^{54}$ The HLP, a longstanding human rights organization based in Los Angeles, provided training and other assistance to the Kurdistan Workers' Party (PKK) in Turkey before the material support statute was passed. In particular, the HLP trained the PKK in human rights advocacy and peace negotiation skills, seeking to support a much abused Kurd minority in Turkey, while encouraging peaceful resolution of the conflict between the Kurds and the Turkish government. Once the material support statute was passed and the Secretary of State designated the PKK a "terrorist organization," the HLP and its members would have faced lengthy prison terms had they continued to provide this training.

In the second case, federal prosecutors charged five young men from Lackawanna, New York, with providing material support to Al Qaeda by attending one of its Afghanistan training camps. ${ }^{55}$ To the government, the five are part of a "sleeper cell," ready and willing to engage in terrorism as soon as the call comes. To the defense, they are a group of misguided religious idealists who found themselves in the training camp, but returned from the trip never intending to engage in violent action of any kind. The remarkable thing is that under the statute's expansive reach, the government wins whichever version is true, because it need not prove that the individuals actually intended to undertake or even to further any terrorist act.

Like the sedition laws of World War I and the communist membership provisions of the Cold War, the material support law allows the government to imprison individuals without proving that they ever sought to further a single act of terrorism. This makes preventive law enforcement much easier, because it frees the government to go after "suspicious" individuals even where it lacks sufficient evidence to charge them with ac-

${ }^{54}$ Humanitarian Law Project v. Reno, 205 F.3d 1130,1133 (9th Cir. 2000), cert. denied, 532 U.S. 904 (2001).

${ }^{55}$ See Indictment, United States v. Goba, No. 02-M-107 (W.D.N.Y. Oct. 8, 2002), available at http://news.findlaw.com/hdocs/docs/terrorism/usgoba 102102ind.html. 
tually perpetrating or even planning a terrorist crime. But as the Cold War so vividly demonstrated, for the same reasons, it makes it virtually inevitable that the government will target and penalize many innocent persons and deter a great deal of nonviolent associational activity.

\section{The Course of Least Resistance- Substituting Administrative Process for Criminal Justice}

Expanding the substantive scope of criminal prohibitions is only the most obvious way to achieve preventive law enforcement. Far more insidious, and far more common, is the exploitation of administrative procedures to avoid the rigors of the criminal process altogether. Administrative processes have proven highly effective in chilling activity of which the government disapproves, in large part because they can be applied without affording their targets the rights of a criminal defendant. But because the rights that attach to the criminal process are for the most part intended to ensure that we do not imprison innocent people, resort to administrative processes carries with it the potential for widespread abuse.

\section{A. Enemy Aliens}

Perhaps the paradigmatic example of an administrative mechanism for preventive law enforcement is the Enemy Alien Act of $1798 .^{56}$ This law-enacted along with the Alien and Sedition Acts, but unlike them, still with us more than two hundred years later-authorizes the President during a declared war to lock up, deport, or otherwise restrict the liberty of any person over fourteen years of age who is a citizen of the country with which we are at war. It requires no individualized finding of culpability, dangerousness, or even suspicion. Because the law provides for deportation and detention without any process at all, it gives the government substantial power to engage in preventive detention. Detainees need not be provided hearings or lawyers, and the government need not prove anything beyond the fact of enemy citizenship. It represents the ultimate form of administrative control over potential threats.

Presidents invoked the Enemy Alien Act during the War of 1812, World War I, and World War II to regulate the activities of all "enemy aliens" and to detain and deport some of them. ${ }^{57}$ Since the law requires a formally declared war, it has not been used since World War II. The dangers of such authority were dramatically illustrated in World War II, when the government extended the rationale for detaining "enemy aliens"

${ }^{56} 50$ U.S.C. $\$ \S 21-24(2000)$.

${ }^{57}$ See generally J. Gregory Sidak, War, Liberty, and Enemy Aliens, 67 N.Y.U. L. REv. 1402 (1992). 
to intern some 110,000 persons $-70,000$ of whom were U.S. citizenssolely for their Japanese descent, without any individualized hearings or trials. ${ }^{58}$ We have since formally apologized for that action and paid reparations to survivors. But as illustrated below, the temptation to use administrative processes for preventive detention continues.

\section{B. Immigration Processes-The Palmer Raids}

In times of crisis that do not reach the level of a formally declared war, the government has relied on another form of administrative detention, also targeted at foreign nationals-immigration law. The most infamous example of the use of immigration authority for preventive detention purposes was the Palmer Raids of the winter of $1919-1920 .{ }^{59}$ The raids were sparked by a series of terrorist bombings in the United States, including mail bombs addressed to Supreme Court Justice Oliver Wendell Holmes, Jr. and numerous other government officials and a bomb that went off outside Attorney General A. Mitchell Palmer's home in Washington, DC. The government responded by mounting a mass nationwide roundup of foreign nationals, not for their role in the bombings, but for their political associations with the Communist Party, the Communist Labor Party, and the Union of Russian Workers. The raids focused on foreign nationals because, lacking a peacetime sedition law, the immigration laws were the only authorization for targeting individuals for their politics. As Acting Secretary of Labor Louis Post observed, "[T]he force of the delirium turned in the direction of a deportations crusade with the spontaneity of water flowing along the course of least resistance." $" 60$

The government ultimately arrested somewhere between four thousand and ten thousand individuals, many without any warrant, conducted illegal searches and seizures in doing so, detained many in overcrowded and unsanitary conditions, and interrogated them without counsel. ${ }^{61}$ The last tactic was seen as critical to obtaining the admissions of political association that would then form the basis for deportation. It was made possible by a last-minute rule change, enacted one business day before most of the arrests took place, that delayed the alien's right to a lawyer

${ }^{58}$ See David Cole, Enemy Aliens, 54 Stan. L. Rev. 953, 989-94 (2002).

${ }^{59}$ See generally Robert K. Murray, Red Scare: A Study in National Hysteria, 1919-1920 (1955); Louis F. Post, The Deportations Delirium of Nineteen-Twenty: A Personal Narrative of an Historic Official Experience (1923); William PreSton, Jr., Aliens and Dissenters: Federal. Suppression of Radicals, 1903-1933, at 208-37 (1963).

${ }^{60}$ Post, supra note 59, at 307.

${ }^{61}$ See Post, supra note 59, at 167 (estimating that approximately six thousand arrest warrants issued and that approximately four thousand warrants executed); Preston, supra note 59, at 221 (estimating ten thousand arrests). Many aliens were arrested without warrants. Post, supra note 59, at 96, 111; Preston, supra note 59, at 221. 
(and to confrontation of the evidence upon which the arrest was based) until the case had "proceeded sufficiently in the development of the facts to protect the Government's interests." ${ }^{62}$ Ultimately, more than five hundred foreign nationals were deported for their political associations; no one was charged with the bombings. ${ }^{63}$ Louis Post, who oversaw most of the deportations and courageously cancelled several thousand deportations, later noted, "In no instance was it shown that the offending aliens had been connected in any way with bomb-throwing or bomb-placing or bomb-making. No explosives were found, nor any firearms except four pistols personally owned and some guns in the 'property room' of an amateur theatrical group." ${ }^{4}$ Nonetheless, there was a limit to what Post could do; as he complained, the laws forced him "to order deportations of many aliens whom not even a lynching mob with the least remnant of righteous spirit would have deported from a frontier town." ${ }^{65}$

From the government's standpoint, immigration proceedings are preferable to criminal proceedings for many reasons. The Supreme Court has long ruled that deportation is not punishment and that, therefore, the rights attaching to criminal trials do not automatically extend to deportation hearings. ${ }^{66}$ Aliens in deportation proceedings have no constitutional right to a lawyer and have a statutory right to a lawyer only if they can find and afford one. ${ }^{67}$ They have no constitutional right to a presumption

\footnotetext{
${ }^{62}$ Murray, supra note 59, at 211; see also Preston, supra note 59, at 214-18. Prior to December 31, 1919, Rule 22, which governed immigration hearings, provided that:

At the beginning of the hearing under the warrant of arrest the alien shall be allowed to inspect the warrant of arrest and all evidence on which it was issued, and shall be apprised that he may be represented by counsel.
}

Constantine M. Panunzio, The Deportation Cases of 1919-1920, at 37 (1921). As amended that day, the rule read:

Preferably at the beginning of the hearing under the warrant of arrest or at any rate as soon as such hearing has proceeded sufficiently in the development of the facts to protect the Government's interests, the alien shall be allowed to inspect the warrant of arrest and all the evidence on which it was issued and shall be apprised that thereafter he may be represented by counsel.

Id.

${ }^{63}$ Post, supra note 59 , at 167.

${ }^{64} \mathrm{Id}$. at 192.

${ }^{65}$ Robert D. Warth, The Palmer Raids, 48 S. Arlantic Q. 1, 18 (1949).

${ }^{66}$ See Fong Yue Ting v. United States, 149 U.S. 698 (1893) (holding that deportation is not punishment and does not require the protections of the criminal process).

678 U.S.C. $\$ 1229 \mathrm{a}(\mathrm{b})(4)(\mathrm{A})(2000)$ (declaring a statutory right to counsel "at no expense to the Government"); Aguilera-Enriquez v. INS, 516 F.2d 565, 568-69 (6th Cir. 1975) (holding that an indigent individual has no constitutional right to counsel in deportation hearings and that counsel must be provided only if necessary to fundamental fairness under due process). Congress has forbidden legal services attorneys from representing any aliens other than lawful permanent residents. See Omnibus Consolidated Rescissions \& Appropriations Act of 1996, Pub. L. No. 104-134, \$ 504(a)(11), 110 Stat. 1321 (prohibiting the use of Legal Service Corporation funding for unlawful aliens). 
of innocence beyond a reasonable doubt, to a jury trial, or to witness confrontation. The Supreme Court has insisted that aliens living in the United States have a due process right to a fundamentally fair hearing, but the contours of that right have not been clearly articulated. ${ }^{68}$ The rules of evidence do not apply. The government asserts the right not only to rely on hearsay but also to deport, detain, and deny immigration benefits to noncitizens on the basis of secret evidence presented in camera and ex parte to the judge, so that neither the noncitizen nor his attorney has any right to confront or rebut it. ${ }^{69}$

\section{Emergency Administrative Detention}

Given the judgment of history that the Japanese internment of World War II occasioned, one might think that the very concept of extending administrative detention to citizens would have been abandoned quickly. Not so. In 1948, in the immediate aftermath of the war, the Justice Department secretly adopted a program, known as "the Portfolio," for interning "dangerous persons" during an emergency declared by the President. ${ }^{70}$ Under this program, which applied to citizens and foreigners alike, the President would suspend the writ of habeas corpus, and mass arrests would be made under a single "master warrant" issued by the Attorney General. The single warrant would also authorize widespread searches and seizures. Those detained would have no right to seek judicial review, but would be limited to an administrative hearing before specially constituted boards of review not bound by the rules of evidence. Their only appeal would be to the President. ${ }^{71}$

In September 1950, Congress independently created its own detention plan, enacted as Title II of the Internal Security Act. ${ }^{72}$ This statute,

${ }^{68}$ See Yamataya v. Fisher, 189 U.S. 86 (1903) (holding that aliens are entitled to due process in proceedings to expel them).

${ }^{69}$ See generally, David Cole, Secrecy, Guilt by Association, and the Terrorist Profile, 15 J. L. \& REL. 267 (2000-2001) (discussing the use of secret evidence in immigration proceedings).

70 See Select Comm. to Study Governmental Operations with Respect to INtelligence Activities, Supplementary Detalled Staff Reports on Intelligence ACtivities AND The Rights of Americans (Book III), S. Rep. No. 94-755, at 438-39 (1976) [hereinafter Church Committee StafF Reports]. For an excellent summary of the detention program, see Robert Justin Goldstein, An American Gulag? Summary Arrest and Emergency Detention of Political Dissidents in the United States, 10 Colum. Hum. RTS. L. REv. 541, 558-61 (1978).

"See generally Church Committee Staff RePorts, supra note 70, at 438-41; Intelligence Activities (Volume 6): Hearings Before the Senate Select Comm. to Study Governmental Operations with Respect to Intelligence Activities, 94th Cong. 416-26 (1975) (Exhibit 26-1, Department of Justice memorandum regarding "Program for Apprehension and Detention of Persons Considered Potentially Dangerous to the National Defense and Safety of the United States"); $i d$. at 658-65 (Exhibits 60-3 to - 6, regarding Department of Justice "Emergency Detention Program," including model warrants).

${ }^{72}$ Act of Sept. 25, 1971, Pub. L. No. 92-128, § 2, 85 Stat. 347. 
which remained on the books until 1971, also authorized emergency detention of dangerous persons, albeit under slightly more restrictive terms than "the Portfolio" provided. As Richard Longaker described Congress's detention program:

[It authorized] detention without arraignment before a judge, the possibility of bail, or a jury trial .... Apprehension and incarceration were based on an administrative finding of prospective guilt in which non-judicial officers utilized a standard of reasonable belief, not probable cause, that a suspect should be held .... The authority of the Attorney General was uncontrolled. He could issue warrants at will and withhold evidence selectively, including the identity of the detainee's accusers, thus bypassing the right of a defendant to confront and cross-examine his accusers. ${ }^{73}$

In 1952, Congress authorized and funded detention centers for suspected subversives in Arizona, California, Florida, Oklahoma, and Pennsylvania. $^{74}$

No one was ever detained under "the Portfolio" or the Internal Security Act programs because no emergency arose. But the very fact that for more than a generation after World War II the federal government planned to detain "dangerous" citizens and foreigners wholly outside the criminal process illustrates how far the notion of substituting administrative process for criminal justice had spread. In addition, the mere existence of these authorities justified the FBI in undertaking widespread political spying for decades, not for any criminal law purpose, but simply so that it could maintain lists of suspicious persons to be detained in a future emergency. At its peak in 1954, the FBI's "Security Index" of people to be detained numbered 26,174 persons. ${ }^{75}$ In the 1960 s, the FBI's list included civil rights and anti-war movement activists, including Dr. Martin Luther King, Jr. ${ }^{76}$ In the late 1960s, the FBI instructed its agents to investigate for potential inclusion on the lists the Students for a Democratic Society, other "pro-Communist New Left-type groups," and even all persons living in "communes." 7

It was not until 1971 that Congress repealed the emergency detention provisions and enacted a provision stating that "no citizen shall be imprisoned or otherwise detained by the United States except pursuant to

${ }^{73}$ Richard Longaker, Emergency Detention: The Generation Gap 1950-7I, 27 W. PoL. Q. 395, 402 (1974).

${ }^{74}$ Wiecek, supra note 21 , at 427.

${ }^{75}$ Church Committee Staff Reports, supra note 70, at 441, 445-46.

${ }^{76}$ See Robert Goldstein, Political Repression in Modern America From 1870 To 1976, at 419 (Univ. of Ill. Press, 2001) (1978).

${ }^{77}$ Сhurch Committee Staff Reports, supra note 70, at 509-18. 
an Act of Congress." 78 Yet the FBI continued to maintain lists of subversive persons until at least 1975, when it revealed the existence of the lists to a congressional committee investigating intelligence abuses and abolished the lists. ${ }^{79}$

\section{Loyalty Review Boards and Congressional Committee Hearings}

During the Cold War, as noted above, the government expressly made subversive speech and association a crime under the Smith Act. But the vast majority of those harmed by the excesses of the Cold War were targeted not through the criminal process but by loyalty review procedures and congressional committee hearings. In both settings, the government was able to inflict a kind of guilt by association while denying its targets critical criminal protections, such as the presumption of innocence and the right to confront the prosecution's evidence.

Loyalty review processes were applied to every federal employee, as well as to many non-federal employees, through copycat programs implemented by state and local governments and private employers seeking to do business with the government. Here, the ostensible targets were disloyal employees. But disloyal was for all practical purposes reduced to "Communist," and one could lose one's job not only for membership in the Party, but even for "sympathetic association" with suspected Communists. ${ }^{80}$ As in the immigration process, the government successfully argued that it need not provide the rights that would apply in a criminal process because denying someone a job did not constitute punishment. Indeed, the courts generally went even further, holding that because employees did not have a liberty or property interest in retaining their jobs, they were not even entitled to due process. ${ }^{81}$

Consider, for example, the case of Dorothy Bailey. ${ }^{82}$ In 1949, Bailey, a personnel trainer with the Civil Service Commission in Washington, D.C., lost her job. A loyalty review board had found that there were "reasonable grounds" to suspect that she was disloyal to the United States. Ms. Bailey never learned the source of those grounds. She was told only in the most general terms that she was suspected of having been associated with the Communist Party, the American League for Peace and Democracy, and the Washington Committee for Democratic Action, all organizations designated by the Attorney General as suspect. At her hearing, she was represented by three of the nation's leading lawyersThurman Arnold, Abe Fortas, and Paul Porter-and she put on a vigorous

${ }^{78} 18$ U.S.C. $\S 4001$ (a) (2000).

${ }^{79}$ Goldstein, supra note 70 , at 572 .

${ }^{80}$ BROWN, supra note 1 , at 5-7; BonTeCOU, supra note 22, at 106-10.

${ }^{81}$ See Bailey v. Richardson, 182 F.2d 46, 57-58 (D.C. Cir. 1950), aff'd by an equally divided court, 341 U.S. 918 (1951).

${ }^{82}$ See generally Alan Barth, The Loyalty of Free Men 111-14 (1951). 
defense. She admitted past membership in the American League but denied all other charges. She asserted her loyalty, offered seventy supporting affidavits and four witnesses to attest to her character, and submitted to all questioning by the hearing examiners. No witness offered evidence against her. As the Court of Appeals for the D.C. Circuit later summarized it, "[T]he record consists entirely of evidence in her favor." 83 Yet the hearing board ruled against her on the basis of undisclosed secret FBI reports relaying accusations by unidentified informants. The court of appeals found nothing illegal or unconstitutional about the process, reasoning that since she had no right to a government job, she was entitled to no due process in her termination. ${ }^{84}$ The Supreme Court affirmed the decision by an equally divided vote. In the end, the best Arnold, Fortas, and Porter could do for Bailey was to hire her as their office manager ${ }^{85}$

Dorothy Bailey did not stand alone. Professor Brown estimated that because loyalty review programs were adopted by federal, state, and local governments and often extended to private employers who sought to do business with the government as well, as many as one in five working Americans were subjected to the loyalty review process in one way or another-by having to take an oath, filling out loyalty disclosure forms, or being subjected to full-scale loyalty review hearings. ${ }^{86}$

The infamous HUAC hearings provided yet another way to effect preventive law enforcement without having to provide the safeguards of the criminal process. HUAC subpoenaed thousands of witnesses to testify about their alleged communist sympathies and to name names. ${ }^{87}$ It operated on the theory of guilt by association, which, as Alan Barth described it, went in two directions: "A group was contaminated by any "subversive' individual who entered it. And, conversely, every member of the group became 'subversive' by the mere fact of membership." 88 Again, because a congressional hearing is not a criminal trial and does not take any liberty or property interest from the witness, the HUAC maintained that it did not need to provide witnesses with the rights they would be entitled to even in a civil trial. Witnesses were frequently confronted with accusations from unidentified informants and denied any opportunity to confront their accusers or to present their own witnesses. Yet the exposure of such proceedings often led private employers to fire those who

${ }^{83}$ Bailey, 182 F.2d at 66 (Edgerton, J., dissenting).

${ }^{84}$ See id. at 58.

${ }^{85}$ See Laura Kalman, Abe Fortas: A Biography 137-41 (1990). See generally Thurman Arnold, Fair Fights and Foul: A Dissenting LaWyer's Life 206-08 (1965).

${ }^{86}$ See BRown, supra note 1, at 181-82.

${ }^{87}$ Michael Linfield, Freedom Under Fire: U.S. Civil Liberties in Times of War 86-87 (1990).

${ }^{88}$ BARTH, supra note 82 , at 62 . 
appeared or were named there, and, therefore, HUAC's chilling effect was substantial. ${ }^{89}$

Alan Barth nicely summed up the use of congressional committees and administrative tribunals for political control during the Cold War:

By the simple stratagem of charging a man with disloyalty, instead of with treason or espionage or sabotage, it is possible to evade the constitutional requirements that he be indicted by a grand jury, that he enjoy a speedy and public trial by an impartial petit jury, that he be informed of the nature and cause of the accusation and confronted with the witnesses against him, that he be accorded the benefit of compulsory process to obtain witnesses in his favor. $\mathrm{He}$ is indicted and tried and sentenced by congressional committee or administrative tribunal, with the same men acting as prosecutors, judges, and jury. The presumption of innocence supposed to surround him is ignored. The mere charge of disloyalty is treated as evidence of guilt. ${ }^{90}$

\section{E. Administrative Process in the War on Terrorism}

All of the measures described above are now seen as having spawned grave and widespread civil liberties abuses. The Palmer Raids were condemned contemporaneously by a blue-ribbon panel of lawyers, including the dean of the Harvard Law School and Professor Felix Frankfurter, ${ }^{91}$ and history has confirmed their judgment. History has also decried the Japanese internment, the HUAC, and the loyalty review boards. These events have taught us the not altogether surprising lesson that when the government is allowed to avoid the safeguards designed to protect the innocent, many innocents suffer. Yet today, our government has once again invoked similar administrative shortcuts in its pursuit of preventive justice.

Perhaps the most dramatic instance of the resort to administrative process in today's war on terrorism is the indefinite and virtually incommunicado detention of foreign nationals and U.S. citizens alike as "enemy combatants." ${ }^{22}$ The Enemy Alien Act does not apply by its terms to

${ }^{89}$ See BARTH, supra note 82, at 64-66 (discussing Hollywood's blacklisting of individuals who refused to testify before HUAC); Ellen SChrecker, Many ARE the Crimes: MCCARTH YISM IN AMERICA, at xiv-xvi (1998).

${ }^{90}$ BARTH, supra note 82 , at 10-11.

9I See Nat'l Popular Gov't League, Report Upon the Illegal Practices of the United States Department of Justice (1920) (authored by R.G. Brown, Zechariah Chafee, Jr., Felix Frankfurter, Ernst Freund, Swinburne Hale, Francis Fisher Kane, Alfred S. Niles, Roscoe Pound, Jackson H. Ralston, David Wallerstein, Frank P. Walsh, and Tyrrell Williams).

${ }^{92}$ At a recent American Bar Association panel on which I appeared, a Justice Depart- 
the war on terrorism because we have not declared war on any nation; there are no citizens of $\mathrm{Al}$ Qaeda. But the government has nonetheless sought to invoke military authority to bypass the criminal process, asserting unreviewable authority to detain in military custody any person whom the President labels an "enemy combatant." Under this authority, the government maintains that it may detain foreign nationals and U.S. citizens alike indefinitely, without a hearing, without access to a lawyer, and without judicial review, simply on the President's say-so. It is using that authority to hold about six hundred foreign nationals at a military base on Guantanamo Bay, Cuba, ${ }^{93}$ and to hold two U.S. citizens-Yaser Hamdi and Jose Padilla-in naval brigs here in the United States.

The courts have thus far ruled that the Guantanamo detainees have no right to judicial review of their detention because they are foreign nationals detained outside the jurisdiction of the United States. ${ }^{94}$ With respect to the two U.S. citizens, the courts have been somewhat less dismissive, at least in preliminary skirmishes, although the ultimate character of the review remains to be seen. Even the U.S. Court of Appeals for the Fourth Circuit, the most conservative federal court of appeals in the nation, has rejected the government's "sweeping proposition" that the courts have no right to review the President's determination that a U.S. citizen is an "enemy combatant." 95 But the courts have not yet specified which standard of review will apply, and it is likely that it will be highly deferential. ${ }^{96}$ The government has argued that if any judicial review of the

ment official objected to the characterization of the enemy combatants' detention as "incommunicado," pointing out that the detainees are allowed visits from the International Red Cross. But that is about it. Those held as enemy combatants are not permitted phone calls, visits, or contact with anyone outside the military other than the International Red Cross and, on occasion, a diplomatic mission. They are permitted to send and receive only highly censored personal mail. They are kept in their cells for all but thirty minutes a week, unless taken out for interrogation. And they cannot consult a lawyer. See Joseph Lelyveld, In Guantanamo, N.Y. REv. Books, Nov. 7, 2002, at 62.

${ }^{93}$ Lelyveld, supra note 92 , at 63 .

${ }_{94}$ See Coalition of Clergy v. Bush, 189 F. Supp. 2d 1036, 1048 (C.D. Cal. 2002), aff'd in part and vacated in part, No. 02-55367, 2002 WL 31545359, at *10 (9th Cir. Nov. 18 , 2002) (vacating the district court's broad holding that detainees do not have rights to habeas corpus review under any circumstances, but upholding the finding that the petitioners in this case lacked standing); Rasul v. Bush, 215 F. Supp. 2d 55, 72-73 (D.D.C. 2002).

${ }^{95}$ Hamdi v. Rumsfeld, 296 F.3d 278, 283 (4th Cir. 2002).

${ }^{96}$ While the Fourth Circuit has implied that some review is appropriate, it has also gone out of its way to insist that whatever review is undertaken must be highly deferential:

If dismissal is thus not appropriate, deference to the political branches certainly is. It should be clear that circumspection is required if the judiciary is to maintain its proper posture of restraint .... The federal courts have many strengths, but the conduct of combat operations has been left to others. The executive is best ... prepared to exercise the military judgment attending the capture of alleged combatants .... The unconventional aspects of the present struggle do not make its stakes any less grave. Accordingly, any judicial inquiry into Hamdi's status as an alleged enemy combatant in Afghanistan must reflect a recognition that government has no more profound responsibility than the protection of Americans, both 
President's "enemy combatant" designation is appropriate, at most the courts should ask only whether the President had "some evidence" to support the designation and should conduct that inquiry without even hearing from the detainee, much less accepting any evidence on his behalf or permitting any confrontation or testing of the government's evidence. ${ }^{97}$

In addition to the enemy combatant designations, the government has dusted off the Palmer Raids tactics, using its immigration authority to arrest and detain large numbers of persons without any showing that they are connected to terrorism. Shortly after September 11, Attorney General John Ashcroft announced that he would use every law on the books, including immigration law, to target and detain "suspected terrorists" in order to prevent future acts of terrorism. ${ }^{98}$ Pursuant to that plan, the Justice Department reported that 1182 individuals had been detained in the first seven weeks of the post-September 11 investigation..$^{99}$ After November 5 , facing criticism that it had arrested so many people but had charged none with any terrorist crimes, the Justice Department simply stopped issuing a running tally of its detentions. ${ }^{100}$ But as the arrests have continued, even a conservative estimate would number the detentions at approximately two thousand as of November 2002, fourteen months after the campaign began. ${ }^{101}$

military and civilian, against additional unprovoked attack.

Id.

${ }^{97}$ See Brief for Respondents-Appellants at 34, Hamdi v. Rumsfeld, 296 F.3d 278 (4th Cir. 2002) (No. 02-6895), available at http://news.findlaw.com/hdocs/docs/terrorism/ hamdirums61902gbrf.pdf.

${ }^{98} \mathrm{John}$ Ashcroft, Prepared Remarks for the U.S. Mayors Conference (Oct. 25, 2001), available at http://www.usdoj.gov/ag/speeches/2001/agcrisisremarks10_25.htm ("Taking suspected terrorists in violation of the law off the streets and keeping them locked up is our clear strategy to prevent terrorism within our borders."); see also John Asheroft, Remarks, Attorney General Ashcroft Outlines Foreign Terrorist Tracking Task Force (Oct. 31, 2001) (transcript available at http://www.usdoj.gov/ag/speeches/2001/agcrisisremarks10_31. htm).

${ }^{99}$ See Dan Eggen \& Susan Schmidt, Count of Released Detainees is Hard to Pin Down, Wash. Post, Nov. 6, 2001, at Al0 (reporting a Department of Justice source who stated that 1182 people had been detained); see also Matthew Brzezinski, Hady Hassan Omar's Detention, N.Y. Times, Oct. 27, 2002, § 6 (Magazine), at 50 (reporting 1147 detainees in November 2001); Todd S. Purdum, Ashcroft's About-Face on the Detainees, N.Y. Times, Nov. 28, 2001, at B7 (reporting over 1100 detained).

${ }^{100}$ See Amy Goldstein \& Dan Eggen, U.S. to Stop Issuing Detention Tallies, Wash. Post, Nov. 9, 2001, at A16; Purdum, supra note 99.

${ }^{101}$ If detentions had continued at the initial rate of 1147 in seven weeks, or approximately six hundred a month, there would be more than eight thousand arrests after fourteen months. It is likely, of course, that the rate of arrests dropped off substantially after the first few weeks, but even so, it is likely that arrests would now number in the range of two thousand. The Justice Department admitted in May, for example, that it had detained nearly six hundred persons in its "Absconder Apprehension Initiative," which selectively targets aliens who come from Arab countries and have outstanding deportation orders. See Dan Eggen, U.S. Search Finds 585 Deportee Absconders, WaSh. Post, May 30, 2002, at A7; see also Memorandum from the Deputy Attorney General, Department of Justice, Guidance for Absconder Apprehension Initiative (Jan. 25, 2002), available at 
The bulk of the detainees have been held on immigration charges. ${ }^{102}$ The immigration detainees have been held and tried in secret. Pursuant to directions from the Attorney General, even if the hearing involves no confidential information of any sort, their cases may not be listed on the public docket, no one may attend their hearings other than their lawyer, and the presiding judges may neither confirm nor deny that the cases exist. ${ }^{103}$ Many detainees were held initially without any charges for weeks. ${ }^{104}$ Many found it difficult to find a lawyer, in part because the government radically restricted their ability to contact anyone outside the prison. ${ }^{105}$ Many have been held for months even after agreeing to depart the country, simply because the FBI has not yet completed its investigation of them. ${ }^{106}$ All of this is possible only because the immigration process is administrative in nature. Were these individuals tried criminally, they would have had a right to a public trial, to be brought before an independent judge within forty-eight hours of their arrest, and not to be detained simply because the FBI had not completed its investigation.

Just as the Palmer Raids turned up no actual bombers and the McCarthy era tactics identified few spies or saboteurs, so also the government's yield of actual terrorists from its current preventive detention program has been staggeringly small. According to Ashcroft, all of the detainees were "suspected terrorists." Yet of the approximately two thousand persons, only four have been charged with any crime relating to terrorism. ${ }^{107}$ None has been charged with involvement in the September 11 crimes, and the vast majority have been affirmatively cleared of any criminal charges by the FBI. As noted above, the government's policy

http://news.findlaw.com/hdocs/docs/doj/abscndr012502mem.pdf.

${ }^{102}$ See generally Cole, supra note 58, at 960-65; Human Rights Watch, Presumption of Guilt: Human Rights Abuses of Post-September 11 Detainees (2002), available at http://www.hrw.org/reports/2002/us911/USA0802.pdf.

${ }^{103}$ See Detroit Free Press v. Ashcroft, 303 F.3d 681 (6th Cir. 2002); North Jersey Media Group, Inc. v. Ashcroft, 308 F.3d 198 (3d Cir. 2002).

${ }^{104}$ See Amnesty Int'L, Amnesty International's Concerns Regarding Post SEPTEMBER 11 Detentions IN THE USA (2002), available at http://www.amnesty-usa.org/ usacrisis/9.11.detentions2.pdf.

105 See Lawyers' Committee for Human Rights, A Year of Loss: Reexamining Civil Liberties Since SePtember 11, at $19 \mathrm{n} .93$ (2002), available at http://www.lchr.org/ us_law/loss/loss_report.pdf.

${ }^{106}$ See Christopher Drew \& Judith Miller, Though Not Linked to Terrorism, Many Detainees Cannot Go Home, N.Y. Times, Feb. 18, 2002, at A1; see also Class Action Complaint and Demand for Jury Trial, Turkmen v. Ashcroft, CV-02-307 (E.D.N.Y. 2002), available at http://news.findlaw.com/hdocs/docs/terrorism/turkmenash41702cmp.pdf; Susan Sachs, Civil Rights Group to Sue Over U.S. Handling of Muslim Men, N.Y. TIMES, Apr. 17,2002 , at A13.

107 See Desmond Butler \& Alan Cowell, Swedish Police Rush to Trace the Trail of Hijacking Suspect, N.Y. Times, Sept. 2, 2002, at A4 (reporting that James Ujaama had been detained since July 2002); Danny Hakim, 4 Are Charged With Belonging To a Terror Cell, N.Y. Times, Aug. 29, 2002, at A1 (reporting that three of the four men charged as part of a Detroit terror cell were initially arrested during post-9/11 preventive detention sweeps and also reporting on the indictment of James Ujaama). 
has been to release and/or deport detainees only after the FBI has cleared them. Yet as of October 2002, Attorney General Ashcroft announced that the INS had deported 431 detainees, and in July 2002, the Justice Department reported that only eighty-one individuals remained in immigration detention. ${ }^{108}$ Thus, by the government's own account, virtually none of those detained as "suspected terrorists" turned out to be terrorists.

A third administrative mechanism for "preventive" law enforcement is the International Emergency Economic Powers Act (IEEPA). ${ }^{109}$ This law, designed to authorize the President to impose economic sanctions on foreign countries in emergency situations, has in recent years been adapted to the task of cutting off funds for designated "terrorist" groups and individuals. President Clinton initiated the extension of IEEPA to political organizations in 1995, when he declared a national emergency with respect to the Middle East peace process and designated twelve organizations-ten Palestinian organizations opposed to the peace process and two Jewish extremist groups-as "specially designated terrorists." The Executive Order also permits the Secretary of State to name additional specially designated terrorists if they are found to be "owned or controlled by, or to act for or on behalf of" an entity designated by the President. "' Shortly after the September 11 attacks, President Bush issued an Executive Order imposing similar financial restrictions on "specially designated global terrorists," and also authorizing the Secretary of Treasury to add to the list anyone who "assist[s] in, sponsor[s], or provide[s] . . support for" or is "otherwise associated" with a designated terrorist. ${ }^{112}$ Designation results in the immediate blocking of all of the entity's assets and makes it a crime to engage in any economic transactions with the designated entity. The statute specifies no substantive criteria for identifying the entities initially designated by the President, leaving that critical decision entirely to the President's discretion. IEEPA affords those designated by the President no opportunity to contest the designation. Further, those groups and individuals subsequently identified by the Secretary of Treasury need only be found to be in some way "associated" with the initially designated entities.

When IEEPA was used solely to impose economic embargoes on foreign countries, it was a relatively noncontroversial form of nation-to-

108 John Ashcroft, Remarks at the U.S. Attorneys Conference (Oct. 1, 2002), available at http://www.justice.gov/ag/speeches/2002/100102agremarkstousattorneysconference.htm; see LAWYERS' COMMITTEE FOR HUMAN RIGHTS, supra note 105, at $27 \mathrm{n} .72$ (citing Letter from Daniel J. Bryant, Assistant Attorney General, U.S. Department of Justice, to Senator Carl Levin, Chairman of Permanent Subcommittee on Investigations, Senate Committee on Governmental Affairs (July 3, 2002)).

10950 U.S.C. $\$ 1701$ (a) $(2000)$.

${ }^{110}$ Exec. Order No. 12,947, 3 C.F.R. 319 (1995), reprinted in 50 U.S.C. $\$ 1701$ (2000).

${ }^{111} I d$. $\S 1$ (a)(iii).

112 Exec. Order No. 13,224 § 1(d), 3 C.F.R. 786, (2001), reprinted in 50 U.S.C.A $\S 1701$ (West Supp. 2002). 
nation diplomacy. But when that same authority is targeted not at countries but at political organizations and individuals, it raises serious constitutional concerns. It allows the President to selectively blacklist disfavored political groups without substantive standards or procedural safeguards, and it allows the Secretary of Treasury to extend those sanctions to individuals based solely on "associations," without regard to the character of the associations. In short, it resurrects the Cold War practice of generating official lists of proscribed organizations without clear substantive guidelines or meaningful procedural safeguards.

Moreover, a little-noticed provision in the USA Patriot Act, enacted in October 2001, amended the IEEPA to authorize the Treasury Department to freeze all assets of any organization merely on the assertion that it is under investigation for potentially violating the IEEPA. The amendment further authorizes the government to defend that freeze order if challenged in court on the basis of secret evidence, presented to the court in camera and ex parte. ${ }^{113}$ Under the investigative provision, the Treasury Department after September 11 froze the assets of two Muslim charities, Global Relief Foundation, Inc., and Benevolence International Foundation. In both cases, it did so without a hearing or any specific charges; the groups were told only that they were "under investigation." And in both cases, the government searched the organizations' offices and seized all of their records, books, and computers. Both organizations, along with a third charity, the Holy Land Foundation, have now been listed as specially designated terrorists and specially designated global terrorists, based not on allegations of criminal conduct but on their alleged associations with other groups designated by the President.

Global Relief Foundation challenged on multiple constitutional grounds both the search and seizure of its offices and the freezing of its assets. In June 2002, a district court rejected all of the challenges. It found that the freezing order did not constitute punishment and that, therefore, protections associated with the criminal process were not applicable. The court upheld both the search and seizure and the freezing order on the basis of secret information submitted ex parte and in camera to the court and not provided to the Global Relief Foundation or its lawyers. ${ }^{14}$ The Holy Land Foundation also challenged its designation on multiple constitutional grounds, and, in August 2002, a district court also rejected its challenges, using similar reasoning. ${ }^{115}$ None of these foundations have been charged with any criminal conduct of any kind, yet all

${ }^{113}$ See Uniting and Strengthening America by Providing Appropriate Tools Required to Intercept and Obstruct Terrorism (USAPATRIOT) Act of 2001, Pub. L. No. 107-56, $\S 106,115$ Stat. 272, 277-78 (amending 50 U.S.C. $\$ 1702(\mathrm{a})(1)(\mathrm{B})$ and adding 50 U.S.C. $\S 1702(\mathrm{c}))$.

${ }^{114}$ See Global Relief Found. v. O'Neill, 207 F. Supp. 2 d 779 (N.D. Ill. 2002). 2002).

${ }^{115}$ See Holy Land Found. for Relief \& Dev. v. Ashcroft, 219 F. Supp. 2d 57 (D.D.C. 
three have been put out of business through these administrative measures.

The lengths to which IEEPA sanctions can be extended are perhaps best illustrated by the case of Mohammed Salah, the only American citizen ever to be listed as a specially designated terrorist. Salah was arrested, interrogated, and convicted in Israel, allegedly on the basis of a coerced confession, for having distributed money to the families of deported leaders of Hamas in the 1990s. He served a five-year sentence in an Israeli jail, was freed, and returned to the United States. ${ }^{116}$ In 1995, however, he was listed as a' specially designated terrorist. ${ }^{17} \mathrm{He}$ had no opportunity to present evidence concerning the circumstances of his confession, his activities in Israel, or anything else. He had no trial, no notice, and no appeal. And as a specially designated terrorist, it became a crime for anyone in the United States to have any economic transactions whatsoever with him. Literally applied, the designation would bar him from buying a loaf of bread from the corner grocer, going to a doctor, hiring a lawyer, or even taking a donation from a friend. In short, he has been subjected to a sort of internal banishment, which, if literally enforced, would lead to his starvation without so much as a hearing, much less a trial. ${ }^{118}$

In sum, the war on terrorism has once again prompted calls for preventive justice and spurred authorities to seek out ways to avoid the safeguards of the criminal process in its effort to protect us. Military custody, immigration detention, and administrative embargoes have all permitted the government to exercise control over "suspicious" individuals and groups without having to prove that any criminal activity was performed, planned, or even contemplated. But precisely because these legal mechanisms-which can have quite devastating effects on their targets-do not require any individualized proof of wrongdoing, they have been and inevitably will be misused against persons engaged in no terrorist or other criminal activity at all.

\section{CONCLUSION}

Those who claim that the United States has avoided the mistakes of the past in its current war on terrorism have failed to look beneath the surface. While it is true that the scope of the wrongs done during World War I, World War II, or the Cold War has not yet been equaled, we are

\footnotetext{
116 See David Johnston, U.S. Prosecutors Suspect an American Citizen of Financing Hamas Terror, N.Y. Times, June 14, 1998, at A20.

${ }^{117}$ List of Specially Designated Terrorists Who Threaten to Disrupt the Middle East Peace Process, 60 Fed. Reg. 41,152 (Aug. 11, 1995).

${ }^{118}$ See Johnston, supra note 116; Ashraf Kalil, U.S. Citizen Accused by Israel of Having Hamas Ties Becomes Test Case for Arab-Americans and Israeli Justice System, CAIRo Times, Aug. 6-10, 1998, at 11.
} 
only in the initial stages of a war likely to be as permanent as the war on drugs or the war on crime. And when one looks not at the quantity but at the quality of our response, it is clear that we have resurrected the very techniques that got us into trouble in the past-namely, expanding the substantive definitions of wrongdoing to encompass otherwise innocent political activity, relying on group identity rather than individual conduct for suspicion, and adopting administrative measures to avoid the safeguards associated with the criminal process.

If the past is any guide, these mistakes will come at substantial cost to the targeted communities, as many innocent persons are swept up in the government's preventive net. But the mistakes may also undermine the war on terrorism itself. Professor Oren Gross has argued that the greatest threat that terrorists pose to a democratic state is not to its physical survival, but to what one might call the survival of principle. ${ }^{119} \mathrm{He}$ argues that what terrorists want is to provoke the state into (over)reacting in ways that violate its own principles, thereby undermining the state's legitimacy and creating sympathy for those allied with the terrorists. ${ }^{120}$ If that is the case, it is all the more critical as we respond to the terrorist threat that we learn from our past mistakes and adhere to the principles that distinguish us from terrorists, for we may well be playing into $\mathrm{Al}$ Qaeda's hands.

A little more than one year after the United States suffered one of the worst attacks on civilian life in modern history, one might expect to find widespread sympathy and support for the United States around the world. But instead, reports of anti-Americanism suggest that hostility to the United States has grown substantially since September 11.21 No doubt much of this resentment is attributable to our unilateral foreign policy. But it likely is also due at least in part to the fact that as we insist that we are fighting a war for our freedom, we have denied those basic freedoms to many "suspicious" persons, the vast majority of whom are foreign nationals of Arab origin and/or Muslim faith. When we sacrifice the very principles that allegedly distinguish us from terrorists, and particularly when we do so in ways that appear to discriminate, we forfeit much of the war on terrorism's legitimacy.

${ }^{119}$ Oren Gross, Cutting Down Trees: Law-Making Under the Shadow of Great Calamities, in The Security of Freedom: Essays on Canada's Antl-Terrorism Bill 39 (Ronald Daniels et al. eds., 2001).

${ }^{120}$ Id. at $40-42$.

${ }^{121}$ See, e.g., Raymond Bonner, Southeast Asia Remains Fertile For Al Qaeda, N.Y. Times, Oct. 28, 2002, at A1; Frank Bruni, Europe Pauses and Grieves, But Takes Issue With U.S., N.Y. Times, Sept. 12, 2002, at B1; Zbigniew Brzezinski, Confronting AntiAmerican Grievances, N.Y. TImes, Sept. 1, 2002, \& 4, at 9; Thomas Friedman, Tone It Down a Notch, N.Y. Times, Oct. 2, 2002, at A27; Neil MacFarquhar, Threats and Responses: Security; For Americans in Mideast, Daily Balance of Risk, N.Y. TIMEs, Oct. 31, 2002, at A12; Craig S. Smith, Saved by U.S., Kuwait Now Shows Mixed Feelings, N.Y. Times, Oct. 12, 2002, at Al1. 
It is understandable that in times of fear, we defer to authority and close our eyes to the wrongs perpetrated in the name of our protection. But history reveals that blind faith is wholly unwarranted. Now more than ever it is critical that we remain true to our principles. There is nothing wrong with prevention when it consists of protecting potential targets of attack or stepping up security at borders, airports, and other vulnerable points. But when prevention translates into the punishment of individuals for what we suspect they may do, rather than for what they have done, it cannot be justified in a democratic society. The safeguards of the criminal process exist for a reason, and whenever we impose punishment or deprive persons of their liberty without adhering to these safeguards, we do more harm than good. The success of the war on terrorism, and indeed of our democratic experiment, requires us to reconsider the shortcuts that we have all too swiftly and predictably adopted. 